\title{
MOTIVATIONS AND BARRIERS OF ENTREPRENEURS IN MOSCOW AND THE MOSCOW REGION
}

\author{
Natalia SULIKASHVILI ${ }^{1}{ }^{*}$, Godefroy KIZABA ${ }^{2}$, Abdelouahid ASSAIDI ${ }^{3}$ \\ ${ }^{1}$ Catholic University, Lille, France \\ ${ }_{2}^{2}$ Politechnic University Hauts de France, Valenciennes, France \\ ${ }^{3}$ Laurentian University, Ontario, Canada
}

Received 7 July 2020; accepted 13 November 2020

\begin{abstract}
The main goal of this research is to examine the motivation of entrepreneurs from Moscow and the Moscow region in conducting entrepreneurial activity in present economic conditions, and to identify the obstacles slowing down this activity. For implementing this goal a survey of 63 small business owners was conducted. To collect the data, authors selected the ME (micro-enterprise), the SB (small business) and the SME (small and medium-sized enterprise). The actors questioned were entrepreneurs and more particularly the heads of companies running an ME, SB or SME in Moscow and its regions. Using research methods as factor analysis and Cronbach's Alpha, a hierarchy of the different motives and entrepreneurial barriers were constructed. Investigation results show that regarding motivations of entrepreneurs, 4 components were obtained: extrinsic motivations composed of 4 items, intrinsic motivations composed of 6 items, motivations linked to independence and autonomy with 3 items and motivations related to the safety and well-being of the family with 3 items. In terms of barriers or obstacles encountered by Russian entrepreneurs, in regards with the literature review, we obtained 5 components: barriers of legitimacy consisting of 3 items, administrative barriers with 3 items, financial barriers with 2 items, managerial barriers with 3 items and finally competitive barriers with 3 items. The novelty of this study is to improve knowledge of the motivations and barriers that entrepreneurs in Moscow and its region encounter in the course of their activity.
\end{abstract}

Keywords: Russian entrepreneurs, motivations, obstacles, entrepreneurial activity.

JEL Classification: M10.

\section{Introduction}

The study of motivations and entrepreneurial barriers is based on theoretical models of performance studies (Blawatt, 1995; Naffziger et al., 1994), which allows to emerge the importance of the objectives pursued by entrepreneurs when creating their businesses. The results obtained by researchers regarding the variable of motivation show that a better understanding of motivation and entrepreneurial barriers contributes to a better understanding of behaviors chosen by entrepreneurs. They give as well a more precise explication of the impact these behaviors have on the performance of their business.

This exploratory study aims to determine the motivations and the barriers of entrepreneurs in Moscow and the surrounding region. It also aims to specify the orientation of motivation and the entrepreneurial barriers and to analyze its specificities. Finally, the third objective attempts to understand through factorial analysis how the motivations and entrepreneurial barriers are consolidated. We have positioned our research in the specific economic context of Russia, linked to sanctions and the economic crisis. Several key questions illustrate this research: what determines motivation for entrepreneurs: extrinsic or intrinsic criteria? And how does the socio-economic environment, family and cultural background influence their entrepreneurial activities? Or, in the opposite case, does it create obstacles to pursuing their entrepreneurial activities?

Despite the fact that since 2018 Russia has started to emerge from the economic recession that begun in 2013, the last seven years were marked by an unfavorable climate for Russian entrepreneurs. International experts have predicted that this economic crisis caused mainly by the fall in oil prices, an aggressive foreign policy, international sanctions and by Russian counter-sanctions will continue. In fact, the European sanctions, following the Ukrainian

${ }^{*}$ Corresponding author. E-mail: natalia.sulikashvili@univ-catholille.fr

Copyright $\odot 2021$ The Author(s). Published by Vilnius Gediminas Technical University

This is an Open Access article distributed under the terms of the Creative Commons Attribution License (http://creativecommons.org/licenses/by/4.0/), which permits unrestricted use, distribution, and reproduction in any medium, provided the original author and source are credited. 
conflict in 2013, renewed for each 6 months contributed to the Russian recession. However, the main cause of the recession is the collapse of oil prices.

The situation worsened dramatically in the second quarter of 2015 (Vitkine, 2015). Analysts found that high inflation (5.8\% in 2016, 12.9\% in 2015 and $15 \%$ in 2014) has diminished the real incomes of the population. After stagnating in 2014, Russian GDP contracted by $1.2 \%$ in 2016 against $3.8 \%$ in 2015 . The year 2016 produced some 3 million additional poor versus 2 million in 2015. In 2017 more than 20.3 million (Quénelle, 2016) were living below the poverty line. In 2019 19\% of Russians living on an income below R 10287 (about 126 EUR) a month. The depreciation of the ruble as well as the consequences of the embargo imposed on the purchase of certain products in Europe and Turkey will increase the price of imported goods, especially food. Even the wealthiest are affected by the crisis as evidenced by the $13 \%$ decline in new car sales in 2016 (Quénelle, 2016).

Russia has paid the highest price because the crisis produced devastating effects: increasing layoffs, closures or liquidations of companies, delays in payment of wages. In 2019, approximately 600000 businesses were officially liquidated in Russia (Nazarova, 2019). In this particular context, Russian entrepreneurs are going through a tumultuous period. Some business leaders have decided to sell their businesses. In this regard, we noticed the increase in offers on sites specializing in the sale of the existing businesses. However, there are not many buyers. Others look for survival solutions for their businesses and adapt to the situation.

Since, this research examines on the one hand the motivations of Moscow entrepreneurs who continue to pursue entrepreneurial activity under these conditions, and, on the other hand, identifies the types of obstacles that slow down their activities. Based on a questionnaire survey administered to 63 entrepreneurs in the Moscow region and SMB owners, we examined the nature of motivating factors and the obstacles to starting a business. We will identify them and classify them according to the importance that these entrepreneurs gave them.

To do that, we have organized our work as follows: in the first section devoted to reviewing the literature, we will delve into the particularities of entrepreneurial motivations and obstacles in Russia. In the second section, we will specify the research methodology adopted in order to carry out this work and present the empirical results. In the last section, we will discuss, interpret our results, and highlight the implications for future research.

\section{Literature review}

\subsection{Motivations of Russian entrepreneurship}

Russian entrepreneurship has developed through different stages. Russian specialists in this field agree that the particular motivations of Russian entrepreneurs have been greatly influenced by unstable socio-economic conditions
(Ivanov, 2007; Grachev, 2001; Nikulenko, 2007; Stolyarenko, 2005). It is important to mention that after 1991 there were also "forced or constrained entrepreneurs". Most of them were employees dismissed from state businesses because of their closure. Their main motivations identified were: "being able to control one's own destiny, the situation"; "being your own boss", "want to bind your professional and personal life", "live to work" in the sense of doing the work that really pleases you and not just the work that comes to meet your family's needs, and the "desire to create a good material situation" (McCarthy et al., 1997). Entrepreneurship is perceived by the population as a way to improve their daily lives and to have a higher income level compared to an employee, which will help to better cope with instability (Chepurenko \& Iakovlev, 2013).

As far as Russian post-soviet entrepreneurs are concerned, they have different characteristics compared to the older generation. They grew up in a different sociopolitical environment and benefited from training in management and marketing. Their main motivations are: "wanting to seize new opportunities", "desire to take up a challenge", "take the risk", "opportunity to earn money", "go to the end of the commitment", "perseverance", "seeking to improve oneself in order to work faster and more efficiently", "possibility of creating a network", "desire to project oneself in the long term on a professional level", and so on (GEM, 2016/17).

The 2019/20 GEM (Global Entrepreneurship Monitor) data also shows that with a country's economic growth, the level of forced entrepreneurship declines as voluntary entrepreneurship increases. Since the start of GEM studies in Russia in 2005, motivations were considered stable. $70 \%$ of entrepreneurs indicated that they were taking advantage of new market opportunities to open their own businesses. Nevertheless, we can see that as of 2012 the proportion of voluntary motivation is starting to fall and in 2013 it reached $61.2 \%$. Some volunteer entrepreneurs, those motivated by the chance to seize an opportunity, evoke the gain of money as one of the main motivations (39.8\% of young entrepreneurs) and $9.1 \%$ of established entrepreneurs have not been able to clearly define what prompted them to start their own business. In 2016, 69\% of established entrepreneurs were ambitious and stated that they saw the benefits of having a business but mention the gain of money as the main motivation (GEM, 2016/17). In 2019, $83,9 \%$ admitted that they are mostly motivated by the gain of money (GEM, 2019/20).

In scientific literature, several authors define the role and importance of motivations. Shane et al. (2003) argued that various motivations influence the entrepreneurial process and the perception of risk (Shane \& Venkataraman, 2000). As internal and/or external forces triggering and directing action, motivation encourages or discourages those who engage in business creation. During this process, the entrepreneur often modifies his ways of seeing or his goals, carries out apprenticeships, his project can 
also evolve, and new partners get involved (Naba Boukari, 2019; Bruton et al., 2010).

Gartner (1985), Bornard et al. (2019) highlighted the need for success, job satisfaction, age, education, and having entrepreneur parents as a variable motivating the individual to start a business. The study carried out by Scheinberg and MacMillan (1988) in eleven countries shows that there are six motivating factors: the need for recognition, wealth, the degree of communitarianism, the need for personal development, the need of independence and the need for escape.

The tools for measuring entrepreneurs' motivations were developed by several researchers (Benzing et al., 2009; Barba-Sánchez \& Atienza-Sahuquillo, 2012; Deci \& Ryan, 2008; Kuratko et al., 1997; Robichaud et al., 2010; Robichaud et al., 2001). This work demonstrates the existence of four categories of motivations (Robichaud et al., 2013): "intrinsic motivations" are when the individual entrepreneur carries out his or her activity for the satisfaction it provides in itself, and not for any consequence that results from it. The commitment is spontaneous, fueled by the interest, curiosity, or the challenge and the activity of creating; "extrinsic or instrumental motivations" which correspond to any commitment in an activity with the aim of achieving any result associated with it. Motivating activity is only a means, or an instrument, to achieve something else. Obtaining a reward or avoiding a sanction are the most common examples. It is not the activity that motivates the individual but the prospect of a reward or the fear of a sanction. Third category of motivations is concerned with the reward which follows the determined behavior (external to work) "motivations linked to the need for independence and autonomy": the individual creates his or her company in order to be free from all external constraints, to be independent and to have full control of his/her life at work. He (the individual) is at the origin of his own actions. The last category "motivations related to the safety and well-being of the family" is a significant contribution to the well-being of the entrepreneur, his family, his community or the territory.

In our study, we will use these measuring instruments to identify and prioritize the motivations of Russian entrepreneurs.

\subsection{Barriers to entrepreneurship for Moscow entrepreneurs}

Concerning barriers to entrepreneurship, Russian researchers identify some of the main causes that hamper the development of entrepreneurship in Russia (Gritsunova \& Lotareva, 2015; Polischuk, 2013; Raizberg et al., 2003).

First of all, it is the complexity of the political and economic situation which causes the decline of industry. The legal basis is insufficient for the protection of entrepreneurs (Bruton \& Ahlstom, 2010; Puffer et al., 2010; Zotova et al., 2016). We also note the low level of legal and economic knowledge of entrepreneurs, and the negative perception of entrepreneurial activity for a part of the population. Despite the fact that the perception of the image and status of the entrepreneur has improved in recent years, entrepreneurship is no longer perceived by the Russian population as the best career choice (Krylova, 2018). In addition, there is insufficient support from the State in the area of entrepreneurship.

Concerning corporate taxation, state policy creates major obstacles for entrepreneurs. The tax rate constitutes a real weight for the development of companies. As a general rule, State policy is not oriented towards the progressive support and sustainability of businesses.

Young entrepreneurs have difficulty with bureaucracy and licensing for their businesses. Obtaining an operating license and authorizations in a short time is virtually impossible. In 2019, experts gave the lowest score of 9 out of 100 possible points to State programs that supported entrepreneurs (GEM, 2019/20). In reality, few entrepreneurs have access to these support programs and their inefficiency is explained by the incompetence of the government officials who created them.

Another barrier is the decline in the purchasing power of the population for the acquisition of consumer products caused by the economic crisis. Poor business ethics in the private and state sectors, the harsh competition environment and the very low social protection of entrepreneurs are also significant obstacles.

In 2007, Kisline had already mentioned three groups of major obstacles. The first are those posed by the State, the second by the banking infrastructure and the third by human resources. If the entrepreneurial spirit is rewarded by professional success and enrichment, unfortunately, for the Russians, the uncertainty of the environment, which is often trying for the employees, causes them to seek protection in the organization that employs them. As a result, the Russian generally prefers to be an employee, even if he is not paid well, then to set up his own business. The situation of an entrepreneur is perceived as unstable (Krylov, 2008).

Thus, the question of barriers to creation and other issues throughout the entrepreneurial process is asked. In this regard, contributions to literature are numerous. In particular, we will cite the 150 obstacles that were encountered in a disparate way by Kouriloff (2000).

Similarly, other studies indicate that those who have created businesses are still faced with institutional constraints such as lack of state support, lack of financial assistance from the government, lack of infrastructure in specific regions, poorly adapted legislation, and lack or inadequacy of entrepreneurial education in the education system (Chu et al., 2007; Kiggundu, 2002). Non-membership in a network, absence or inadequacy is a social barrier in establishing long-term business relationships, as is aversion to risk and the permanent fear of failure because of uncertainty of the future. A network mobilizes to the same extent the personal resources of the representatives and the resources of the organizations in which 
these representatives work. Woven behind contractual facades, networks structure the Russian business world. They go through organizations, but do not lock themselves in them. It is a powerful means of project development, rapidly mobilizing many actors with the necessary skills or resources. Access to network business environments requires influential pre-established relationships (Krylov, 2008).

Some resources are essential and have an impact on a company's success from the start. We can cite access to information, business relationships, capital and markets. Lack of capital and their gathering are the main difficulty encountered by young entrepreneurs at the beginning of their creation (Blanchflower \& Oswald, 1998; Henderson \& Robertson, 1999; Lane, 2002; Li, 2007; Robertson et al., 2003).

Lack of market and partner information, financing, marketing skills, financial and management expertise are other barriers described by Roberson et al. (2003). The perception of lack of skills comes from lack of training and lack of experience in an appropriate area when the business begins to exist. The perception of the risk of losing capital comes from economic and political factors (such as legislation and bureaucracy) that discourage entrepreneurs. Lack of management knowledge, lack of functional expertise, lack of capacity to recruit, to train, re-train, and lack of a skilled labor force are very costly in business.

Lack of human capital can also be seen as a barrier to entrepreneurship as inadequate training and entrepreneurial education hinder the development of human capital and limit the employment opportunities of individuals (Kovalainen, 2007; Shane, 2008).

Barriers to entrepreneurship are therefore psychological, socio-cultural and political. Similarly, when one observes the overall context of creation, the barriers linked to the territory are of intermediate importance. Therefore, once the company is created and developed, can a hierarchy be established between the various entrepreneurial barriers? Are there links between these barriers?

\section{Methodology}

\subsection{Sample and questionnaire}

The literature review and the measurement instruments applied to study different populations of entrepreneurs in many countries led us to create a questionnaire which inputs are oriented towards the motivations and obstacles of entrepreneurs. This questionnaire was submitted to established entrepreneurs in Moscow and Moscow region. To obtain the information sought for this study, we selected the ME (micro-enterprise), the SB (small business) and the SME (small and medium-sized enterprise) as fields of interest to understand the motivation and the entrepreneurial barriers. The actors questioned are entrepreneurs and more particularly the heads of companies running an $\mathrm{ME}, \mathrm{SB}$ or SME in Moscow and its regions.

We produced a set of items from the literature review and the field study. It consists of 18 items related to entrepreneurial objectives and 15 items relating to entrepreneurial barriers. The measurement instruments were used to establish the objectives of the entrepreneurs and their obstacles. They are based on the measurement instruments developed and validated by Robichaud et al. $(2001,2013)$ and Kuratko et al. (1997). More precisely, the selected measuring instruments were developed following a review of the literature which made it possible to identify the motivations and the barriers most often invoked in the research on this subject.

To do this we chose the 5-point Likert scale (odd post), which, according to Evrard et al. (2003), is one of the best known in opinion studies. Entrepreneurs (business owners) are asked to mark a number indicating the degree of importance ( $1=$ no importance, $5=$ very important $)$.

A first mailing was sent out in November 2017, generating 21 responses. A second postal revival in March 2018 resulted in 28 responses. The return rate is mainly due to the length of the questionnaire (5 pages). As the return rate was too low to be validated, we contacted them directly by phone and/or email and resent them several times. And finally we ended up getting 63 responses. In the Table 1 we present respondents profile.

Table 1. Respondents profile

\begin{tabular}{|l|c|l|c|}
\hline \multicolumn{2}{|c|}{ Entrepreneurs' characteristics $(\mathrm{n}=63)$} & \multicolumn{2}{c|}{ Business characteristics $(\mathrm{N}=63)$} \\
\hline & Percentage & & Percentage \\
\hline Gender & & Full time personnel & $64.9 \%$ \\
\hline Women & $38.1 \%$ & 5 employees or less & $9.6 \%$ \\
\hline Men & $61.9 \%$ & 6 to 10 employees & $25.6 \%$ \\
\hline Age & & 11 employees and over & $25.4 \%$ \\
\hline 20 years to 29 years & $22.2 \%$ & Business figures & $7.9 \%$ \\
\hline 30 years to 39 years & $20.6 \%$ & 20000 and under & $19.0 \%$ \\
\hline 40 years to 49 years & $30.2 \%$ & 20000 and under & $7.9 \%$ \\
\hline 50 years to 59 years & $20.6 \%$ & 50001 to 100000 & \\
\hline 60 years and over & $6.3 \%$ & 100001 to 150000 & \\
\hline
\end{tabular}


End of Table 1

\begin{tabular}{|c|c|c|c|}
\hline \multicolumn{2}{|c|}{ Entrepreneurs' characteristics $(n=63)$} & \multicolumn{2}{|c|}{ Business characteristics $(\mathrm{N}=63)$} \\
\hline & Percentage & & Percentage \\
\hline Education & & 150001 to 200000 & $6.3 \%$ \\
\hline Bachelor or less & $12.7 \%$ & 200001 to 1 million & $20.7 \%$ \\
\hline $\mathrm{Bac}+2$ (DUT, BTS) & $14.3 \%$ & 1 million and more & $12.7 \%$ \\
\hline License to Master & $61.9 \%$ & Size of the city (population) & \\
\hline Professional Degree & $3.2 \%$ & 10000 and under & $6.3 \%$ \\
\hline Ph.D. & $7.9 \%$ & 10001 to 24999 & $3.2 \%$ \\
\hline Management experience & & 25000 to 39999 & $1.6 \%$ \\
\hline No experience & $25.4 \%$ & 40001 to 64999 & $1.6 \%$ \\
\hline 1 to 5 years & $36.5 \%$ & 65000 to 99999 & $1.6 \%$ \\
\hline 6 to 10 years & $22.2 \%$ & 100000 to 250000 & $11.1 \%$ \\
\hline 11 to 15 years & $6.4 \%$ & 250000 and more & $74.6 \%$ \\
\hline 16 years or more & $9.5 \%$ & Activity area & \\
\hline Experience - sector of activity & & Retail business & $23.8 \%$ \\
\hline No experience & $17.5 \%$ & Wholesale & $15.9 \%$ \\
\hline 1 to 5 years & $42.7 \%$ & Services (transport, personal Services) & $36.5 \%$ \\
\hline 6 to 10 years & $22.3 \%$ & Manufacturing & $3.2 \%$ \\
\hline 11 to 15 years & $9.5 \%$ & Construction & $6.3 \%$ \\
\hline 16 years or more & $8.0 \%$ & New technologies & $7.9 \%$ \\
\hline Start in the business & & Other & $6.3 \%$ \\
\hline Entrepreneur by creation & $61.9 \%$ & Business owner for & \\
\hline Entrepreneur by acquisition & $20.6 \%$ & 1 to 5 years & $53.9 \%$ \\
\hline Entrepreneur by inheritance & $12.7 \%$ & 6 to 10 years & $19.1 \%$ \\
\hline Franchise & $3.2 \%$ & 11 to 15 years & $14.3 \%$ \\
\hline Business background & & 16 years or more & $12.7 \%$ \\
\hline Already owned a business & $49.2 \%$ & Number of hours works per week & \\
\hline Never owned a business & $50.8 \%$ & 35 hrs or less & $17.5 \%$ \\
\hline Entrepreneur by creation & $61.9 \%$ & 36 to $40 \mathrm{hrs}$ & $23.8 \%$ \\
\hline Entrepreneur by acquisition & $20.6 \%$ & 41 to $50 \mathrm{hrs}$ & $35.0 \%$ \\
\hline Entrepreneur by inheritance & $78.9 \%$ & 51 to $60 \mathrm{hrs}$ & $6.4 \%$ \\
\hline Franchise & $49.2 \%$ & more than $60 \mathrm{hrs}$ & $17.5 \%$ \\
\hline Financial assistance from the State & & Need & \\
\hline Yes & $1.6 \%$ & Yes & $42.9 \%$ \\
\hline No & $98.4 \%$ & No & $57.1 \%$ \\
\hline \multicolumn{2}{|c|}{ Financial aid from a non-profit organization } & & \\
\hline Yes & $11.1 \%$ & & \\
\hline No & $88.9 \%$ & & \\
\hline
\end{tabular}

\subsection{Principal component analysis}

Principal component analysis (PCA) seeks a solution to the overall variance of the measured variables. In addition, it seeks a solution where the components are orthogonal (i.e. independent of each other) ${ }^{1}$. Regardless of the

\footnotetext{
1 Although it is possible to make orthogonal or oblique rotations in PCA, this use does not respect the bases of the PCA, namely a unique solution and independent components which explain a decreasing proportion of the variance.
}

correlation matrix, there is always a PCA solution. The PCA maximizes the explained variance.

On the geometric level, all these methods involve projecting an $n$ dimensional hyperplane onto a hyperplane of much smaller dimension, where the main concepts extracted from this analysis can be expressed much more clearly (Usunier et al., 2000).

In order to do this, we have therefore studied the interrelations between the different variables for each question, then regrouped these variables in limited components or groups and then established a hierarchy based 
on the explanatory value of each of the variables factors. The principle resolution is to find successively a first factor best summarizing the information contained in the initial matrix, then a second factor, independent of the first, best summarizing the residual information and so on. A number of factorial axes are thus obtained. The sum of the values associated with these axes is equal to the total variance. Some variables are correlated to two or even multiple axes with different correlation coefficients. To solve this problem and better interpret the factors, we have performed a Varimax rotation in the factor space in order to increase the value of the correlation coefficients of certain variables by bringing them closer to one of the axes. To validate the reliability of the internal coherence, we calculated the Cronbach alpha, allowing us to check if all the elements converge towards the same intensity of response.

\subsection{Cronbach's alpha}

Cronbach's alpha coefficient is a good measure of the internal consistency of a latent variable; the acceptable values are normally above 0.70 (Nunnally, 1978). However, values close to 0.60 can be accepted (Hair et al., 2006), especially if the variable is measured with few items.
George and Mallery (2003), propose the following "rules of thumb" for interpreting Cronbach's alpha coefficient: unacceptable $<0.60$; poor 0.60 to 0.69 ; acceptable from 0.70 to 0.79 ; good 0.80 to 0.89 ; excellent $>0.89$. It is possible that 2 observed variables measure a single latent variable, but this may lead to problems in identifying the conceptual model later (Brown, 2006; Kline, 2005). It is advisable to have a minimum of 3 items or better still, 4 items (Hair et al., 2006).

The interpretation of the alpha coefficient is a function of the number of items: the more items, the higher the alpha coefficients, although inter-item correlations are rather average (Cortina, 1993; Worthington \& Whittaker, 2006).

\section{Results of the research}

\subsection{Obtained results}

With the help of measurement instruments developped by Kuratko at al. (1997) and Robichaud et al. (2010), we were able to identify the four categories of motivations of entrepreneurs and to prioritize them for the better understanding of the entrepreneurial landscape. We obtained 4 components: extrinsic motivations composed of 4 items,

Table 2. Factor analysis into main components of motivation criteria

\begin{tabular}{|c|c|c|c|c|}
\hline Motivations & $\begin{array}{l}\text { Extrinsic } \\
\text { motivations }\end{array}$ & $\begin{array}{l}\text { Intrinsic } \\
\text { motivations }\end{array}$ & $\begin{array}{l}\text { Independence } \\
\text { and autonomy }\end{array}$ & $\begin{array}{l}\text { Safety and well-being } \\
\text { of the family }\end{array}$ \\
\hline $\begin{array}{l}\text { - Create a business that allows me to live } \\
\text { comfortably }\end{array}$ & 0.745 & & & \\
\hline - Create my own job & 0.740 & & & \\
\hline - Increase my company's sales and profits & 0.825 & & & \\
\hline $\begin{array}{l}\text { - Increase the amount of money I get from my } \\
\text { business }\end{array}$ & 0.753 & & & \\
\hline CRONBACH'S ALPHA & 0.804 & & & \\
\hline - Rise to a challenge guaranteeing employment & & 0.680 & & \\
\hline - Proving that I can succeed in what I do & & 0.767 & & \\
\hline $\begin{array}{l}\text { - Save (savings account, pension funds) for my } \\
\text { retirement }\end{array}$ & & 0.617 & & \\
\hline - Make myself known & & 0.564 & & \\
\hline - Helping my personal development & & 0.668 & & \\
\hline - Do a job I like to do & & 0.731 & & \\
\hline CRONBACH'S ALPHA & & 0.700 & & \\
\hline - Be able to decide what I want to do & & & 0.584 & \\
\hline - Be my own boss & & & 0.708 & \\
\hline - Maintain a sense of freedom and independence & & & 0.746 & \\
\hline CRONBACH'S ALPHA & & & 0.656 & \\
\hline - Providing jobs for my children & & & & 0.779 \\
\hline - Building something that benefits my children & & & & 0.725 \\
\hline - Be closer to my children & & & & 0.624 \\
\hline CRONBACH'S ALPHA & & & & 0.633 \\
\hline EXPLAINED VARIANCE & 27.167 & 14.129 & 13.397 & 10.493 \\
\hline
\end{tabular}


intrinsic motivations composed of 6 items, motivations linked to independence and autonomy with 3 items and motivations related to the safety and well-being of the family with 3 items.

The total variance explained is $65.08 \%$. This means that after purification, $34.92 \%$ of the motivating factors remain unexplained by the chosen variables. In this case, new variables would have to be added, making it more difficult to collect data on the ground. The internal coherence (Cronbach's alpha) between the four components varies from 0.626 to 0.804 , which means an acceptable internal consistency (Table 2).

Table 3. Cumulative average of motivational factors

\begin{tabular}{|l|c|c|}
\hline \multicolumn{1}{|c|}{ Axes } & Average & Standard deviation \\
\hline $\begin{array}{l}\text { Independence and } \\
\text { autonomy }\end{array}$ & 3.96 & 1.09 \\
\hline Extrinsic motivations & 3.85 & 1.01 \\
\hline Intrinsic motivations & 3.44 & 1.21 \\
\hline $\begin{array}{l}\text { Safety and well-being of } \\
\text { the family }\end{array}$ & 3.10 & 1.33 \\
\hline
\end{tabular}

However, when we calculate the average of the four components obtained (Table 3), the highest is the "independence and autonomy" component (3.96), followed by the "extrinsic motivations" component (3.85), the "intrinsic motivations" component (3.44) and finally the "safety and well-being of the family" component with an average of 3.10. The cumulative average shows the ratio of one component to the other. This is statistically interesting; however, we will base our analysis on the results of the PCA because this analysis seems to be more representative to us, reflecting the answers of the interviews.

The results of the PCA show that extrinsic motivations with the proper value (27.167\% of the variance) occupy the first place for Russian entrepreneurs. This first factor includes the variables "creating a business that allows me to live comfortably" (0.745), "creating my own job" (0.740), "increasing sales and profits in my business" (0.825), and "increasing money I get from my business" (0.753). In fact, most people surveyed have created their business to earn a living. This shows that entrepreneurial motivation can be explained more for financial reasons than for reasons of safety and the well-being of the family.

The intrinsic motivations are in second place, with a proper value of $14.129 \%$ of the variance. Within this factor, we find the following variables: "meeting a job-guaranteeing challenge" (0.680), "proving that I can do what I do" (0.767), "saving for my retirement" (0.617), "make myself known" (0.564), and "do a job that I love" (0.731). This demonstrates that entrepreneurs attach great importance to doing a job they like and contributing to their personal development.

The independence and autonomy component takes third place (13.397\% of the variance). This factor includes the variables: "maintain a sense of freedom and independence" (0.746); "being my own boss" (0.708) and "being able to decide what I want to do" (0.584). The notion of independence is one of the main motivations mentioned by entrepreneurs. This factor indicates a high level of experience and competence that gives the opportunity to have free choices about their lifestyle, the desire to control their life and having a sense of important personal responsibility in decision making. It must be understood as a desire for emancipation and respect for the work done by oneself.

The "safety and family welfare" factor comes in last, with a value equal to $10.49 \%$ of the variance. "Contributing to the well-being of the family" implies a need for institutional and family power or a desire to influence others by serving them and a personal power to exercise altruism and feel important to one's family. In this case, influence is about the desire to gain respect and family and social admiration. The entrepreneur hopes to create a successful business that will grow and will have an influence on his immediate environment.

In terms of barriers or obstacles encountered by Russian entrepreneurs, in regards with different authors mentioned in the literature review we obtained 5 components: barriers of legitimacy consisting of 3 items, administrative barriers with 3 items, financial barriers with 2 items, managerial barriers with 3 items and finally competitive barriers with 3 items.

The total variance explained is $72.64 \%$. This means that after purification, $27.36 \%$ of the obstacle factors remains unexplained by the selected variables. In this case, new variables would have to be added, making it more difficult to collect data on the ground. The internal consistency (Cronbach's alpha) between the five components varies from 0.633 to 0.834 , which means an acceptable internal consistency (Table 4).

Table 4. Principal Component Analysis of barriers and obstacles of generations of entrepreneurs

\begin{tabular}{|c|c|c|c|c|c|}
\hline \multicolumn{1}{|c|}{ Objectives } & $\begin{array}{c}\text { Legitimacy } \\
\text { barriers }\end{array}$ & $\begin{array}{c}\text { Administrative } \\
\text { barriers }\end{array}$ & $\begin{array}{c}\text { Financial } \\
\text { barriers }\end{array}$ & $\begin{array}{c}\text { Managerial } \\
\text { barriers }\end{array}$ & $\begin{array}{c}\text { Competitive } \\
\text { barriers }\end{array}$ \\
\hline - Difficulties in exporting our products & 0.661 & & & & \\
\hline - Inadequate transport/road system & 0.801 & & & & \\
\hline - Credibility problem (recognition) & 0.787 & & & & \\
\hline CRONBACH'S ALPHA & $\mathbf{0 . 7 7 4}$ & & & & \\
\hline - Administrative burden & & 0.716 & & & \\
\hline
\end{tabular}


End of Table 4

\begin{tabular}{|c|c|c|c|c|c|}
\hline Objectives & $\begin{array}{l}\text { Legitimacy } \\
\text { barriers }\end{array}$ & $\begin{array}{c}\text { Administrative } \\
\text { barriers }\end{array}$ & $\begin{array}{c}\text { Financial } \\
\text { barriers }\end{array}$ & $\begin{array}{c}\text { Managerial } \\
\text { barriers }\end{array}$ & $\begin{array}{c}\text { Competitive } \\
\text { barriers }\end{array}$ \\
\hline - Complex business registration process & & 0.773 & & & \\
\hline - High social costs & & 0.810 & & & \\
\hline CRONBACH'S ALPHA & & 0.726 & & & \\
\hline - Obtaining short-term financing & & & 0.809 & & \\
\hline - Obtaining long-term financing & & & 0.848 & & \\
\hline ALPHA DE CRONBACH & & & 0.834 & & \\
\hline - Employees who cannot be trusted & & & & 0.785 & \\
\hline - Lack of management training & & & & 0.592 & \\
\hline - Lack of marketing training & & & & 0.742 & \\
\hline ALPHA DE CRONBACH & & & & 0.741 & \\
\hline - Too much competition (tough competition) & & & & & 0.771 \\
\hline - Low economic growth & & & & & 0.791 \\
\hline - Unsecured location & & & & & 0.501 \\
\hline ALPHA DE CRONBACH & & & & & 0.663 \\
\hline EXPLAINED VARIANCE & 36.153 & 13.236 & 8.846 & 7.732 & 6.669 \\
\hline
\end{tabular}

Table 5. Cumulative average of factors of barriers/obstacles

\begin{tabular}{|l|c|c|}
\hline \multicolumn{1}{|c|}{ Axes } & Averages & Standard deviation \\
\hline Managerial barriers & 3.16 & 1.23 \\
\hline Administrative barriers & 3.11 & 1.26 \\
\hline Competitive barriers & 3.04 & 1.07 \\
\hline Financial barriers & 2.89 & 1.14 \\
\hline Legitimacy barriers & 2.76 & 1.30 \\
\hline
\end{tabular}

The Table 5 above presents the cumulative averages for each of the four components. The component with the highest average is the "managerial barriers" component (3.16), followed by "administrative barriers" (3.11), "competitive barriers" (3.04), "financial barriers" (2.89) and finally "barriers of legitimacy" (2.76). As explained earlier in interpreting the motivation results, our analysis will be based on the results of the PCA.

The most important barriers encountered by Russian entrepreneurs are those of legitimacy $(36.153 \%$ of the variance). "Difficulties in exporting our products" (0.774), "inadequate transport system" (0.801), and "recognition problem" (0.787). The poor perception of the entrepreneurial activity and the difficulty to export the products are very pronounced.

Administrative barriers with an own value equal to $13.236 \%$ of the variance comes in second place and are determined by the heavy and sometimes contradictory administrative and financial system. This factor is composed of the variables: administrative burden (0.761), complex business registration process (0.773), and high social costs (0.810).

The financial barriers follow the administrative with an own value of $8.846 \%$ of the variance. The variables "obtaining short-term financing" (0.809) and "obtaining long-term financing" (0.848) demonstrate that, in the current situation, access to financing is very complex with very high interest rates. These variables also show that entrepreneurs do not trust banks and try to work on their own funds or address friends, family, etc.

The managerial barriers ( $7.723 \%$ of the variance) occupy the fourth place. We find the following variables: "employees who cannot be trusted" (0.785), "lack of management training" (0.592), and "lack of marketing training" (0.742). This is certainly due to the high turnover in Russian companies and the difficulty of retaining employees. Besides this, Russian employees, based on their generational affiliation, do not systematically have training in management or marketing because these disciplines have only been taught for twenty years.

Competitive barriers (6.669\% of the variance) ranked last with the variables "too much competition" (0.771), "low economic growth" (0.791), and "unsecured location" (0.501). In fact, with economic growth being weak, competition is not the first occupation of Russian entrepreneurs.

\subsection{Discussion}

As a first step, we set out to paint a general descriptive picture of the entrepreneurial motivations and barriers as perceived by our entire sample and highlighted in the survey we conducted to carry out this study. Through Principal Component Analysis and Cronbach's Alpha, we have highlighted four components for motivations: extrinsic motivation, intrinsic motivation, independence and autonomy, and family safety and well-being. We can also distinguish five components for obstacles: legitimacy, 
administrative, financial, managerial and competitive barriers.

As far as motivations are concerned, we find that extrinsic motivations come in first place and that most of those surveyed have created their business to earn a living, so financial reasons prevail over reasons of safety and family well-being. This fact is probably explained by the particular socio-economic context, the conditions and the atypical path of the development of Russian entrepreneurship. Since the birth of the new Russia, the status of the entrepreneur became prestigious because it ensured a certain lifestyle and allowed one to participate in the formation of the functional market in Russia. The choice to undertake the creation of a business is often motivated by the prospects of financial gain and the lack of opportunity to find a job that would provide a comfortable standard of living.

Intrinsic motivations come second. These motivations are more pronounced among young entrepreneurs who wish to take up a challenge and carry out their creative ideas. These young entrepreneurs were trained in other socio-economic conditions. They have more management skills, and fluency in foreign languages. In fact, they were able to start their businesses during a period of the liberal market and were not influenced by the transition period. Some of them grew up in entrepreneurs' families which gave them a taste for entrepreneurship.

The independence and autonomy component ranks third and reflects the fact that entrepreneurs consider themselves to have sufficient knowledge and skills to carry out their entrepreneurial activity and do not have to depend on a structure as an employee. The relatively high level of qualifications characterizes Russian entrepreneurs and contributes to this dynamic, especially for entrepreneurs aged 26-34.

The safety and family well-being factor comes last. In fact, unstable socio-economic conditions and lack of confidence in the banking system led entrepreneurs to have a more pragmatic logic that indicates that financial gain will provide family welfare and ensure family safety. The importance of work, financial gain and family well-being are linked for Russian entrepreneurs. The GEM study (2019/2020) confirmed this trend. According to it, 93\% of entrepreneurs surveyed highlighted the high level of the importance of their work. According to the same study, entrepreneurs are happier and more satisfied with family well-being than those not engaged in entrepreneurial activity.

As far as barriers are concerned, we find that the most important barriers facing Russian entrepreneurs are the barriers of legitimacy. Despite the privileged status that entrepreneurship provides, the lack of strong values associated with entrepreneurship in Russian culture negatively influences the development of entrepreneurship. We cannot ignore the particular historical context of the development of entrepreneurship (Puffer et al., 2010; Volchek et al., 2013). The new class of entrepreneurs was born in Russia at a dizzying speed. Nevertheless, the sudden change of elites and the lack of information on the part of the State led to a double-faceted representation of this class among the Russians. Public opinion perceived entrepreneurs as a class of manipulators and mobsters. In the press of the time, there were many articles on the "ghost class" and the odnodnevki enterprises (shell companies, or businesses that exist for short period of time). These representations have improved since then, but today we see that people engaged in entrepreneurial activity are much more favorable to entrepreneurship compared to those who are not (GEM, 2019/2020).

Administrative barriers come next and are determined by the heavy and sometimes contradictory administrative and financial system. Changing government policy is a major constraint on the development of entrepreneurship. Critical factors are the duration of licensing, tax and taxation policy as well as very unstable structural market conditions. As an example, we can mention the fact that in 2019 experts observed that $11.5 \%$ of corporate closure in Russia was caused by the change in legislation regulation and taxation (GEM, 2019/2020).

Financial barriers follow the administrative and are determined by the current financial crisis and fluctuations in the exchange rate between the ruble and the euro, partly due to the Western economic sanctions. The ineffectiveness of State programs for business support is explained by the inefficiency of the State officials who manage and implement them. Access to finance remains very limited. This concerns bank loans and government financing. The results of our study show that family and friends are more frequent sources of finance than banks and state institutions.

Finally, the managerial barriers ranks fourth. They are explained by new ways of doing business that require new skills to manage a business well. Individual characteristics and personal background such as skills and entrepreneurial education and training significantly affect the entrepreneurial spirit. Thus, a low level of entrepreneurial education, a low level of management qualification, a lack of qualified mangers, and the difficulty of finding a friendly and motivated staff, in short, a weak management culture, are obstacles to entrepreneurship. Russians without entrepreneurial education are exposed, as is the case in Western Europe, to Western business ideas and concepts. These ideas and concepts must be included in the curricula of Russian universities.

As far as competition is concerned, it is a fairly recent phenomenon and constitutes in itself an important problem. In the USSR it did not exist because it was regarded as an unnecessary dispensation of productive forces: the whole industry was conceived and created as a single factory without competitors. Even today the laws on competition are not in good order. We find that the past and current economic conditions influence the structure and hierarchy of motivations and obstacles of Moscow entrepreneurs. But their aspirations are not radically different from those of other countries. They aspire to economic freedom, innovation, creativity and the reduction of 
administrative barriers. In this country of risk and great opportunities, the strong human potential represents a major asset.

\section{Conclusions}

In conclusion, this research confirms that motivations and barriers to entrepreneurial activity include economic, organization and behavioral components. Based on a survey of 63 business creators in Moscow and the Moscow region, we have tried to identify the main motivations and barriers that these entrepreneurs encounter throughout their activity. From this perspective, we focused on the question: "what are the main motivations and barriers of Russian entrepreneurs?"

Through Principal Component Analysis and Cronbach's Alpha, we found four components for motivations: extrinsic motivation, intrinsic motivation, independence and autonomy, and family safety and well-being. We also distinguished five components for obstacles: legitimacy, administrative, financial, managerial and competitive barriers.

Due to the conditions caused by the crisis and sanctions, entrepreneurs are motivated by material gain and aspire to have stability because the conditions created by this economic environment and by the state pushes them to take care of themselves through business rather than through just the desire for business. This shows that to start an entrepreneurial activity in Russia at the current moment simply for the desire of it is not worth the effort, even though these motivations are just as important for people to have.

Concerning the barriers, we find that on the one hand public opinion and the perception of entrepreneurs by the public constitutes the largest barrier and that society has not yet totally changed its attitude towards entrepreneurship. On the other hand, the state policy in the field of business development in Russia is inefficient.

The results obtained are interesting and undoubtedly require further study. The data collected, which improves knowledge of the motivations and barriers that entrepreneurs in Moscow and its region encounter in the course of their activity, can serve as a basis for university education and training and support schemes for entrepreneurs in areas of communication, project management, change management, stress resistance, business strategy and business and accounting management.

This study can open a new field of observation of the new generations of entrepreneurs. Lüthje and Fanke (2004) show that entrepreneurial intentions are directly affected by perceptions of barriers to entry. In connection with this, we believe that our questionnaire can be modified and adapted to study the barriers of creative project promoters in order to better accompany them.

The stakes of these results for public decision-makers are multiple in the perspective of economic development based in particular on the creation and promotion of entrepreneurship.

\section{References}

Ahlstrom, D., \& Bruton, G. D. (2010), Rapid institutional shifts and the co-evaluation of entrepreneurial firms in transition economies. Entrepreneurship Theory and Practice, 34(3), 531554. https://doi.org/10.1111/j.1540-6520.2010.00373.x

Barba-Sánchez, V., \& Atienza-Sahuquillo, C. (2012). Entrepreneurial behavior: impact of motivation factors on decision to create a new venture. Investigaciones Europeas de Dirección y Economía de la Empresa, 18(2), 132-138. https://doi.org/10.1016/S1135-2523(12)70003-5

Benzing, C., Chu, H. M., \& Kara, O. (2009). Entrepreneurs in Turkey: a factor analysis of motivations, success factors, and problems. Journal of Small Business Management, 47(1), 5891. https://doi.org/10.1111/j.1540-627X.2008.00262.x

Blanchflower, D. G., \& Oswald, A. J. (1998). What makes an entrepreneur? Journal of Labor Economics, 16(1), 26-60. https://doi.org/10.1086/209881

Blawatt, K. (1995). Defining the entrepreneurs: a conceptual model of entrepreneurship. In $12 e$ colloque annuel $d u$ CCPME (Conseil canadien de la PME et de l'entrepreneuriat) (pp. 13-37). Thunder Bay, Ontario. Octobre.

Bornard, F., Verzat, C., \& Gaujard, C. (2019). Un détour par l'imaginaire pour comprendre les fondements psychosociocognitifs de l'éducation entrepreneuriale. Revue de l'entrepreneuriat, 1(18), 109-140. https://doi.org/10.3917/entre.181.0109

Brown, T. A. (2006). Confirmatory factor analysis for applied research. Guilford Press.

Bruton, G. D., Ahlstrom, D., \& Li, H. L. (2010). Institutional theory and entrepreneurship: where are we now and where do we need to move in the future? Entrepreneurship Theory and Practice, 34(3), 421-440. https://doi.org/10.1111/j.1540-6520.2010.00390.x

Chepurenko, A., \& Iakovlev, A. (2013). Hrestomatia: teoria predprinimatel'stva. Rossijskij Jurnal menedjmenta, 11(2), 102-121.

Chu, H. M., Benzing, C., \& Mcgee, C. (2007). Ghanaian and Kenyan entrepreneurs: a comparative analysis of their motivations, success, characteristics, and problems. Journal of Development Entrepreneurship, 12(3), 295-322. https://doi.org/10.1142/S1084946707000691

Cortina, J. M. (1993). What is coefficient alpha: an examination of theory and applications. Journal of Applied Psychology, 78(1), 98-104. https://doi.org/10.1037/0021-9010.78.1.98

Deci, E. L., \& Ryan, R. M. (2008). Facilitating optimal motivation and psychological well-being across life's domains. Canadian Psychology/Psychologie canadienne, 49(1), 14-23. https://doi.org/10.1037/0708-5591.49.1.14

Evrard, Y., Pras, B., \& Roux, E. (2003). Market, études et recherches en marketing. Dunod, Paris.

Gartner, W. B. (1985). A conceptual framework for describing the phenomenon of new venture creation. Academy of Management Review, 10(4), 696-706.

https://doi.org/10.5465/amr.1985.4279094

GEM. (2016/17). Russie. https://gsom.spbu.ru/files/docs/gem_russia_2016-2017.pdf

GEM. (2019/20). Russie. https://www.c4e.org.cy/reports/2019/ gem-2019-2020-global-report.pdf

George, D., \& Mallery, P. (2003). SPSS for Windows step by step: a simple guide and reference. Allyn \& Bacon.

Grachev, I. (2001). Razvitie malogo predprinimatel'stva. Den'gi $i$ kredit, 11, 69-81.

Gritsunova, S. V., \& Lotareva, K. M. (2015). Razvitie malogo predprinimatel'stva v Rossii. Mir Nauki, 2, 105-117.

Hair, J., Black, B., Babin, B., Anderson, R., \& Tatham, R. (2006). 
Multivariate data analysis. Upper Saddle River, Prentice-Hall.

Henderson, R., \& Robertson, M. (1999). Who wants to be an entrepreneur? Young attitudes to entrepreneurship as a career. Education and Training, 41(5), 236-245. https://doi.org/10.1108/00400919910279973

Ivanov, M. A. (2007). Organizatsia kak vash instrument: Rossiiskii mentalitet i praktika biznesa. Akademia.

Kiggundu, M. N. (2002). Entrepreneurs and entrepreneurship in Africa: what is known and what needs to be done. Journal of Developmental Entrepreneurship, 7(3), 239-258.

Kisline, D. (2007). Petit entrepreneur russe: motivations, buts et innovations [PhD dissertation, Rennes University, France]. https://halshs.archives-ouvertes.fr/halshs-0026029

Kline, R. (2005). Principles and practice of structural equation modeling. Guilford.

Kouriloff, M. (2000). Exploring perceptions of a priori barriers to entrepreneurship: a multidisciplinary approach. Entrepreneurship Theory and Practice, 25(2), 59-79. https://doi.org/10.1177/104225870002500204

Kovalainen, A. (2007). Influencing attitudes and skills for entrepreneurship and SME growth. In J. Potter \& A. Proto (Eds.), Promoting entrepreneurship in South East Europe: policies and tools. OECD.

Krylov, V. (2008). Culture et gestion en Russie: entre l'efficacité et l'incertitude. In E. Davel, J.-P. Dupuis, \& J.-F. Chanlat (Eds.), Gestion en contexte interculturel: approches, problématiques, pratiques et plongées. Presses de l'Université Laval et Téléuniversité UQAM, Québec.

Krylova, Y. (2018). Administrative corruption and its effects on Russian Entrepreneurs: a regional aspect. Journal of Small Business \& Entreprneurship, 30(2), 121-137. https://doi.org/10.1080/08276331.2017.1383764

Kuratko, D., Hornsby, J., \& Naffizger, D. (1997). An examination of owner's goals in sustaining entrepreneurship. Journal of Small Business Management, 35(1), 24-33.

Lane, D. (2002). Hopes and aspirations of young achievers on the young enterprise programme. In Working Paper 7 (Bristol Business School).

Li, W. (2007). Ethnic entrepreneurship: studying Chinese and Indian students in the United States. Journal of Developmental Entrepreneurship, 12(4), 449-466. https://doi.org/10.1142/S1084946707000769

Lüthje, C., \& Franke, N. (2004). Entrepreneurial intentions of business students: a benchmarking study. International Journal of Innovation and Technology Management, 1(3), 33-41.

McCarthy, D., Puffer, S., \& Naumov, A. (1997). Partnering with Russia's new entrepreneurs: Software Tsarina Olga Kirova. European Management Journal, 15(6), 269-288. https://doi.org/10.1016/S0263-2373(97)00048-0

Naba Boukari, M. (2019). Les facteurs clés de succès de l'entrepreneuriat des immigrés au Niger: cas des salons de coiffure. Revue Congolaise de Gestion, 1(27), 129-157. https://doi.org/10.3917/rcg.027.0129

Naffziger, D. W., Hornsby, J. S., \& Kuratko, D. F. (1994). A Proposed research model of entrepreneurial motivation. Entrepreneurship Theory and Practice, 18(3), 29-42. https://doi.org/10.1177/104225879401800303

Nazarova, K. (2019). Tchislo zakryvshihsia biznesov v dva raza prevysilo tchislo otkryvshyhsia. Economics. https://www.rbc. ru/economics/06/06/2019/5cf7bc9b9a79474f236c46a3

Nikulenko, T. G. (2007). Psihologiya menedjmenta. Phenix, Rostov na Dony.

Nunnally, J. C. (1978). Psychometric theory. MC Graw-Hill.
Polischuk, L. (2013). Institutional performance. In M. Alexeev \& S. Weber (Eds.), The Oxford handbook of the Russian economy (pp. 189-220). OUP USA Oxford Handbooks in Economics. https://doi.org/10.1093/oxfordhb/9780199759927.013.0010

Puffer, S. M., McCarthy, D. J., \& Boisot, M. (2010). Entrepreneurship in Russia and China: the impact of formal institutional voids. Entrepreneurship Theory and Practice, 34(3), 441-467. https://doi.org/10.1111/j.1540-6520.2009.00353.x

Quénelle, B. (2016). En Russie, la classe moyenne touchée par la crise économique. La Croix. http://www.la-croix.com/ Economie/Monde/En-Russie-classe-moyenne-touchee-criseeconomique-2016-11-28-1200806293

Raizberg, B. A., Lozovskii, L. Sh., \& Starodubtseva, E. B. (2003). Sovremennyi Ekonomicheskii Slovar. Moskva.

Robertson, M., Collins, A., Medeira, N., \& Slater, J. (2003). Barriers to start-up and their effects on aspirant entrepreneurs. Education and Training, 45(6), 308-316. https://doi.org/10.1108/00400910310495950

Robichaud, Y., Cachon, J. C., \& Haq, R. (2010). Motives, succes factors and barriers among Canadian females entrepreneurs: the case of Greater Sudbury. Entrepreneurial Practice Review, 1(2), 36-48.

Robichaud, Y., Mcgraw, E., Cachon, J. C., \& Haq, R. (2013). L'influence des motivations entrepreneuriales sur la performance des PME. Journal of Small Business \& Entrepreneurship, 26(4), 409-428.

https://doi.org/10.1080/08276331.2013.822143

Robichaud, Y., Mcgraw, E., \& Roger, A. (2001). Toward the development of a measuring instrument for entrepreneurial motivation. Journal of Developmental Entrepreneuriat, 6(2), 189-201.

Scheinberg, S., \& Macmillan, I. C. (1988). An 11 country study of motivations to start a business. Babson College, Wellesley.

Shane, S. (2008). The illusions of entrepreneurship: the costly myths that entrepreneurs, investors and policy makers live. Yale University Press, CT.

Shane, S., \& Venkataraman, S. (2000). The promise of entrepreneurship as a field of research. Academy of Management Review, 25(1), 217-226. https://doi.org/10.5465/amr.2000.2791611

Shane, S., Locke, E. A., \& Collins, C. J. (2003). Entrepreneurial motivation. Human Resource Management Review, 13(12), 257-279. https://doi.org/10.1016/S1053-4822(03)00017-2

Stolyarenko, A. M. (2005). Psikhologiya menedzhmenta. Akademia.

Usunier, J. C., Easterby-Smith, M., \& Thorpe, R. (2000). Introduction à la recherche en gestion. Economica, Paris.

Vitkine, B. (2015). La Russie s'enfonce dans la récession. https://www.lemonde.fr/economie/article/2015/08/11/la-russie-s-enfonce-dans-la-recession_4720725_3234.html

Volchek, D., Jantunen, A., \& Saarenketo, S. (2013). The institutional environment for international entrepreneurship in Russia: Reflections on growth decisions and performance in SMEs. Journal of International Entrepreneurship, 11(4), 320350. https://doi.org/10.1007/s10843-013-0115-z

Worthington, R. I., \& Whittaker, T. A. (2006). Scale development research: a content analysis and recommendations for best practices. The Counseling Psychologist, 34(3), 806-838. https://doi.org/10.1177/0011000006288127

Zotova, A., Mantulenko, V., Kraskova, N., Kislov, A., \& Rowland, Z. (2016). New values as the basis for innovation. International Journal of Economic Perspectives, 10(3), 94-100. 